\title{
Hubungan dukungan sosial dan efikasi diri dengan motivasi berprestasi pada remaja awal dan tengah yang tinggal di panti asuhan di Bali
}

\author{
Ida Bagus Purwa Arsha Manuaba dan Luh Kadek Pande Ary Susilawati \\ Program Studi Psikologi, Fakultas Kedokteran, Universitas Udayana \\ pandeari@unud.ac.id
}

\begin{abstract}
Abstrak
Remaja yang ditelantarkan atau berpisah dari orangtua akan mencari alternatif untuk menggantikan fungsi keluarga yang hilang agar hak-haknya tetap terpenuhi, melalui alternatif berbasis panti asuhan. Remaja yang tinggal di lingkungan panti asuhan sebagian besar akan mengalami tekanan dan masalah selama tinggal di panti asuhan, hal ini dikarenakan dukungan berupa bantuan dari pengasuh yang kurang didapatkan oleh remaja, lingkungan panti asuhan yang berbeda dengan lingkungan tempat tinggal, serta adanya perbedaan norma, kebiasaan, dan budaya yang berbeda dengan daerah asalnya. Remaja yang tinggal di panti asuhan perlu mendapatkan dukungan sosial untuk mengurangi tekanan yang dirasakan sehingga remaja dapat meningkatkan motivasi berprestasi selama tinggal di panti asuhan. Efikasi diridinyatakan dapat membantu individu dalam mengatasi tekanan yang dihadapi selama tinggal di panti asuhan, serta dapat mempermudah remaja untuk meningkatkan motivasi berprestasi selama tinggal di panti asuhan di Bali. Subjek dalam penelitian ini adalah 95 orang remaja awal dan tengah yang tinggal di panti asuhan. Hasil uji regresi berganda menunjukkan koefisien regrresi sebesar 0,574 dan koefisien determinasi sebesar 0,329, dengan signifikansi sebesar 0,000 ( $<<0,05)$, dengan demikian terdapat hubungan dukungan sosial dan efikasi diri dengan motivasi berprestasi pada remaja awal dan tengah yang tinggal di panti asuhan di Bali.Koefisien beta terstandarisasi dari dukungan sosial menunjukkan nilai sebesar 0,368 dan signifikansi $0,000(p<0,05)$, sehingga dukungan sosial berhubungan secara signifikan dengan motivasi berprestasi pada remaja awal dan tengah. Koefisien beta terstandarisasi dari efikasi diri menunjukkan nilai sebesar 0,303 dan signifikansi $0,002(\mathrm{p}<0,05)$, sehingga efikasi diri berhubungan secara signifikan dengan motivasi berprestasi pada remaja awal dan tengah.
\end{abstract}

Kata kunci: motivasi berprestasi, dukungan sosial, efikasi diri, remaja panti asuhan, Bali

\begin{abstract}
Adolescents who are abandoned or separated from parents will look for alternatives to replace lost family functions to ensure their rights are fulfilled, through alternative home-based institutions, adolescents who live in the orphanage will experience the most pressure and problems during their stay in the orphanage, because support in the form of assistance from caregivers less obtained by adolescents, the differences between environment of orphanage and place where they lived, and the differences in norms, habits, and cultures that are different from the area of origin. Adolescents who live in orphanages need to get social support to reduce the perceived pressure so that adolescents can improve achievement motivation during their stay in the orphanage. Self-efficacy can help individuals to cope with the pressures they face during their stay in the orphanage, it can also make it easier for teenagers to improve their achievement motivation during their stay in orphanages in Bali.Subjects in this study were 95 early and middle adolescents who live in orphanages. The result of multiple regression test shows the regression coefficient of 0,574 and the coefficient of determination equal to 0.329 , with significance equal to $0,000(\mathrm{p}<0,05)$, thus there is a correlation of social support and self efficacy with achievement motivation in early and middle adolescents who live in orphanages in Bali. Standardized beta coefficient from social support shows a value of 0,368 , and significance of $0,000(p<0,05)$, hence social support has significance correlation with achievement motivasion of early and middle adolescene. Standardized beta coefficient from self efficacy shows a value of 0,303 , and significance of $0,002(p<0,05)$, hence self efficacy has significance correlation with achievement motivasion of early and middle adolescene.
\end{abstract}

Keyword: achievement motivation, social support, self-efficacy, adolescent orphanage,Bali 


\section{LATAR BELAKANG}

Bagi seorang anak, orang terdekat yang bisa membantu untuk mendapatkan dukungan, kasih sayang dan juga akses terhadap berbagai kebutuhan hidup seperti mendapatkan akses pendidikan adalah keluarga, terutama orangtua. Pada kenyataannya tidak semua anak masih memiliki orangtua atau tinggal bersama dengan keluarga, bahkan ada sebagian dari anak yang ditelantarkan sejak kecil. Hal ini dapat terjadi karena masalah ekonomi, perceraian atau kematian anggota keluarga, serta ketidakharmonisan dalam keluarga dapat menyebabkan hilangnya fungsi keluarga.

Masalah-masalah yang terjadi akibat tidak utuh suatu keluarga dapat menyebabkan anak khususnya yang telah memasuki masa remaja akan dapat merasakan kurang perhatian dan kasih sayang dari orangtua, bahkan harus berpisah dan tinggal jauh dari keluarga. Remaja yang berpisah dari keluarga kemudian mencari alternatif untuk menggantikan fungsi keluarga yang hilang agar hak-haknya tetap terpenuhi, melalui pengasuhan alternatif berbasis panti (Teja, 2014).

Panti asuhan bertanggung jawab untuk memberikan pelayanan pengganti dalam pemenuhan kebutuhan fisik, mental, dan sosial pada anak asuhnya, sehingga anak dan remaja yang tinggal di panti asuhan memperoleh kesempatan yang luas, tepat dan memadai bagi perkembangan kepribadian yang sesuai dengan harapan (Nelson \& Kliegman, 1996). Pada kenyataan, harapan tentang peran dan fungsi panti asuhan seringkali tidak dapat diwujudkan secara optimal oleh pihak panti asuhan. Teja (2014) menyatakan bahwa panti asuhan seolah menjadi harapan bagi orangtua agar anak-anak dapat tetap bersekolah, makan, dan melangsungkan kehidupan. Remaja yang tinggal di panti asuhan akan mengalami ketidakmampuan dalam memenuhi kebutuhan perkembangan secara optimal, seperti kebutuhan berupa materi, kelekatan yang aman dengan orangtua, kebutuhan akan kebebasan, dan penerimaan sosial (Santrock, 2007).

Ketidakmampuan remaja dalam memenuhi kebutuhan perkembangan dapat berdampak pada motivasi berprestasi yang dirasakan (Gunarsa, 2008). Motivasi berprestasi merupakan suatu usaha untuk mencapai sukses dan bertujuan untuk berhasil dalam kompetisi dengan suatu ukuran keunggulan.

Perasaan terkekang dan ketidakbebasan yang dialami oleh remaja yang tinggal di panti asuhan dapat menimbulkan perasaan tidak nyaman yang dapat berpengaruh pada motivasi dalam mencapai prestasi. Santrock (2007) menyatakan bahwa masa remaja dikenal sebagai masa badai dan stres, sehingga perasaan terkekang yang dialami oleh remaja akan menyebabkan remaja rentan mengalami stres, yang bertolak belakang dengan memotivasi diri untuk mencapai prestasi.

Oren (2012) dalam penelitiannya memaparkan anak-anak yang berada di panti asuhan cenderung memiliki tingkat keputusasaan yang tinggi dibandingkan dengan anak-anak yang tinggal bersama keluarga, sehingga memicu motivasi berprestasi yang rendah. Anak-anak panti asuhan cenderung tidak berani memandang masa depan, bahkan memiliki ekspektasi negatif akan masa depan. Stevenson (1952) juga memaparkan bahwa anak-anak panti asuhan pada umumnya menunjukkan kurang memiliki keinginan atau hasrat dalam hal prestasi, serta memiliki kemandirian yang rendah. Permasalahan yang terkait pada kondisi internal anak-anak panti asuhan tersebut bukan tidak mungkin akan mengakibatkan rendahnya prestasi yang dimiliki, karena faktor motivasi atau dorongan keinginan untuk berprestasi merupakan salah satu faktor penting yang turut menentukan prestasi yang dapat dicapai oleh individu. Hal ini didasari dari pemikiran Winkel (1996) dimana motivasi diartikan sebagai daya penggerak dan dorongan yang timbul dalam diri individu untuk memperoleh keberhasilan dalam proses belajar.

Idealnya, remaja yang tinggal di panti asuhan diharapkan mampu termotivasi untuk berprestasi, remaja yang telah tinggal di panti asuhan ditugaskan untuk belajar, hal ini bertujuan agar remaja dapat mandiri saat dewasa. Hal ini didukung dari penelitian Lely Amalia dan Indera Ratna (2014) yang menyatakan bahwa remaja yang tinggal di panti asuhan diharapkan mampu untuk tekun dalam belajar sehingga dapat termotivasi untuk berprestasi, serta dapat mandiri saat dewasa. Pada kenyataannya tidak semua remaja yang tinggal di panti asuhan dapat termotivasi untuk berprestasi, dikarenakan remaja kurang mendapatkan dukungan berupa perhatian, kasih sayang, serta kurangnya bantuan yang diberikan oleh pengasuh serta teman sebaya membuat remaja kesulitan dalam mencari jalan keluar ketika menghadapi masalah seperti dalam penyelesaian tugas sekolah (Santrock, 2003). Pada masa transisi ini, remaja dipandang dari dua sisi yang berbeda, di satu sisi remaja ingin menjadi individu yang mandiri tanpa bantuan orangtuanya, namun di sisi lain remaja masih membutuhkan bantuan dari orangtua (Santrock, 2003).

Sarafino (1994) menyatakan dukungan sosial adalah bantuan yang diterima individu dari orang lain atau kelompok di sekitarnya dengan membuat individu merasa nyaman, dicintai, dan dihargai. Konsep operasional dari dukungan sosial adalah perceived support (dukungan yang dirasakan), yang memiliki dua elemen dasar diantaranya adalah persepsi bahwa ada sejumlah individu yang dapat mengandalkan saat dibutuhkan dan derajat kepuasan terhadap dukungan yang ada (Dimatteo, 2004). Hal ini terlihat dari hasil penelitian yang dilakukan Agustiani pada tahun 2002 yang mengatakan bahwa, remaja masih menunjukkan ketergantungan terhadap orangtua terutama jika dihadapkan pada masalah penting yang menyangkut kehidupannya.

Dukungan atau keterlibatan orangtua sebagai orang terdekat yang dimiliki oleh seorang anak menjadi faktor yang memegang peranan penting sebagai penentu motivasi berprestasi. Hayes (2012) dalam penelitiannya mengungkapkan terdapat hubungan antara keterlibatan orangtua dengan motivasi berprestasi yang dicapai anak.

Faktor-faktor yang memengaruhi motivasi belajar untuk dapat berprestasi adalah salah satunya yaitu efikasi diri (Damyati dan Mudjiono, 2006). Efikasi diri memainkan peranan penting dalam motivasi untuk berprestasi, individu memotivasi dirinya 
sendiri dan mengatur perilaku dengan menggunakan pemikiran tentang masa depan sehingga individu tersebut membentuk keyakinan yang kuat terhadap kemampuan dirinya akan melakukan usaha lebih besar ketika individu tersebut gagal dalam menghadapi tantangan (Bandura,1997).

Individu yang memiliki efikasi diri yang tinggi cenderung untuk memfokuskan perhatian dan usahanya pada tuntutan tugas dan berusaha meminimalisasi kesulitan yang mungkin terjadi. Pervin dan John (dalam Bandura, 1997) mengemukakan individu yang mempunyai efikasi diri yang tinggi akan lebih memiliki motivasi belajar untuk dapat berprestasi yang tinggi pula. Hal ini dicerminkan dengan besarnya usaha yang dilakukan serta ketekunannya dalam mengatasi rintanganrintangan yang ada. Individu akan terus mengerjakan tugastugasnya dan tidak mudah menyerah dan bertahan apabila menemui kesulitan-kesulitan. Individu yang memiliki efikasi diri yang tinggi akan berusaha lebih keras di dalam mengatasi rintangan-rintangan yang ada. Begitu juga sebaliknya semakin efikasi diri individu rendah, individu cenderung tidak dapat memfokuskan perhatian dan usahanya pada tuntutan tugas dan tidak akan meminimalisasi kesulitan yang mungkin terjadi. Pervin dan John (dalam Bandura, 1997) menyatakan individu yang mempunyai efikasi diri yang rendah akan lebih memiliki motivasi belajar dan mencapai prestasi yang rendah pula.

Berdasarkan uraian di atas, penelitian ini dilakukan untuk mengetahui apakah dukungan sosial dan efikasi diri memiliki hubungan dengan motivasi berprestasi remaja yang tinggal di panti asuhan di Bali.

\section{METODE PENELITIAN}

\section{Tipe Penelitian}

Penelitian ini menggunakan metode penelitian kuantitatif. Metode kuantitatif dapat diartikan sebagai metode penelitian yang berlandaskan pada filsafat positivisme, metode yang digunakan untuk meneliti pada populasi atau sampel tertentu, pengumpulan data menggunakan instrumen penelitian, analisis data bersifat statistik, metode penelitian dengan tujuan untuk menguji hipotesis yang telah ditetapkan (Sugiyono, 2014).

\section{Hipotesis Penelitian}

\section{Hipotesis Mayor}

H0 : Tidak terdapat hubungan yang signifikan antara dukungan sosial dan efikasi diri dengan motivasi berprestasi pada remaja yang tinggal di panti asuhan di Bali.

$\mathrm{Ha} \quad$ : Terdapat hubungan yang signifikan antara dukungan sosial dan efikasi diri dengan

motivasi berprestasi pada remaja yang tinggal di panti asuhan. Hipotesis Minor

H0 : Tidak terdapat hubungan yang signifikan antara dukungan sosial dengan motivasi berprestasi pada remaja yang tinggal di panti asuhan di Bali.

$\mathrm{Ha}$ : Terdapat hubungan yang signifikan antara dukungan sosial dengan motivasi berprestasi pada remaja yang tinggal di panti asuhan.

H0 : Tidak terdapat hubungan yang signifikan antara efikasi diri dengan motivasi berprestasi pada remaja yang tinggal di panti asuhan di Bali.
Ha : Terdapat hubungan yang signifikan antara efikasi diri dengan motivasi berprestasi pada remaja yang tinggal di panti asuhan.

\section{Variabel dan Definisi Operasional}

Variabel yang digunakan dalam penelitian ini adalah dukungan sosial dan efikasi diri sebagai variabel bebas serta motivasi berprestasi sebagai variabel tergantung. Dukungan sosial merupakan ketersediaan sumber daya yang memberikan kenyamanan fisik dan psikologis yang didapat melalui interaksi individu dengan orang lain sehingga individu tersebut merasa dicintai, diperhatikan, dihargai, dan merupakan bagian dari kelompok sosial (Sarafino dan Smith, 2011). Efikasi diri merupakan penilaian serta keyakinan individu terhadap kemampuan yang dimilikinya untuk menghadapi suatu tantangan dalam hidupnya melalui pengorganisasian serangkaian tindakan, sehingga akan didapatkan hasil akhir yang positif (Bandura, 1997). Motivasi berprestasi merupakan dorongan yang ada pada diri individu untuk mencapai sukses dan menghindari kegagalan, yang menimbulkan kecenderungan perilaku untuk mempertahankan dan meningkatkan suatu keberhasilan yang telah dicapai dengan berpedoman pada patokan prestasi terbaik yang dicapai oleh dirinya maupun orang lain (McClelland, 1987).

\section{Responden}

Populasi yang digunakan dalam penelitian ini adalah remaja awal dan tengah.Adapun kriteria sampel yang digunakan pada penelitian ini adalah sebagai berikut: remaja yang tinggal di panti asuhan di Bali, remaja usia 12-17 tahun, dan bersedia menjadi responden penelitian.

Pengambilan sampel dalam penelitian ini menggunakan metode sampel acak yaitu cluster sampling. Cluster sampling merupakan teknik yang digunakan untuk menentukan sampel bila objek yang akan diteliti atau sumber data sangat luas (Sugiyono, 2014). Sampel yang terpilih adalah remaja usia 1217 tahun yang tinggal di panti asuhan di Denpasar dengan jumlah 15 panti asuhan. Total sampel dalam penelitian ini adalah 95 orang remaja usia 12-17 tahun yang tinggal di panti asuhan di Denpasar. Responden yang dilibatkan dalam penelitian ini adalah yang telah memenuhi kriteria dan mengisi identitas diri secara lengkap.

\section{Tempat Penelitian}

Pengambilan data tryout pertama dilakukan pada tanggal 25 Januari 2018 sampai 28 Januari 2018. Selanjutnya, pengambilan data tryout kedua dilakukan pada tanggal 22 Februari 2018 sampai 23 Februari 2018. Penyebaran kuesioner penelitian dilaksanakan di 15 panti asuhan di Denpasar, yaitu Panti Asuhan Darma Jati II, Panti Asuhan Tat Twam Asi, Panti Asuhan Sunya Giri, Panti Asuhan Elisama, Panti Asuhan Anugerah, Panti Asuhan Tunas Bangsa, Panti Asuhan Jodie O'Shea House, Panti Asuhan Eben Haizer, Panti Asuhan Bala Keselamatan, Panti Asuhan Putra William Booth, Panti Asuhan Muhammadiyah, Panti Asuhan KH Mansyur Putri, Panti Asuhan KH Mansyur Putra, Panti Asuhan Sakinah, dan Panti Asuhan Hidayatuloh. 


\section{Alat Ukur}

Alat ukur yang digunakan pada penelitian ini adalah skala motivasi berprestasi, skala dukungan sosial dan skala efikasi diri. Skala motivasi berprestasi disusun berdasarkan lima komponen yang dikemukakan oleh McClelland (1987) yang memiliki koefisien validitas yang bergerak dari 0,260 sampai 0,728 dan koefisien reliabilitas sebesar 0,741 . Skala dukungan sosial disusun berdasarkan empat komponen yang dikemukakan oleh Sarafino dan Smith (1991) yang memiliki koefisien yang bergerak dari 0,273 sampai 0,588 dan koefisien reliabilitas sebesar 0,862 . Skala efikasi diri menggunakan modifikasi skala yang disusun oleh Rustika (2014) yang memiliki koefisien yang bergerak dari 0,265 sampai 0,505 dan koefisien reliabilitas sebesar 0,773 .

Pada skala motivasi berprestasi terdapat 20 aitem yang gugur dan hasil uji validitas menunjukkan nilai koefisien korelasi aitem berkisar antara 0,260 sampai 0,728 dengan koefisien Alpha $(\alpha)$ sebesar 0,741 yang artinya skala motivasi berprestasi mampu mencerminkan $74,10 \%$ variasi yang terjadi pada skor murni responden. Pada skala dukungan sosial terdapat 22 aitem yang gugur dan hasil uji validitas menunjukkan nilai koefisien korelasi aitem berkisar antara 0,273 sampai 0,588 dengan koefisien Alpha $(\alpha)$ sebesar 0,862 yang artinya skala dukungan sosial mampu mencerminkan $86,20 \%$ variasi yang terjadi pada skor murni responden. Pada skala efikasi diri terdapat 20 aitem yang gugur dan hasil uji validitas menunjukkan nilai koefisien korelasi aitem berkisar antara 0,265 sampai 0,505 dengan koefisien Alpha $(\alpha)$ sebesar 0,773 yang artinya skala efikasi diri mampu mencerminkan $77,30 \%$ variasi yang terjadi pada skor murni responden.

Ketiga skala disusun berdasarkan bentuk skala likert yang terdiri dari pernyataan positif (favorable) dan pernyataan negatif (unfavorable) dengan empat pilihan jawaban yaitu Sangat Sesuai (SS), Sesuai (S), Tidak Sesuai (TS), dan Sangat Tidak Sesuai (STS). Valid berarti instrument tersebut dapat digunakan untuk mengukur apa yang seharusnya diukur (Sugiyono, 2014). Pengujian validitas yang digunakan dalam penelitian ini adalah validitas isi dan validitas konstruk. Validitas isi merupakan validitas yang diestimasi melalui pengujian terhadap isi tes dengan analisis rasional atau melalui professional judgment. Uji validitas dalam penelitian ini akan diukur menggunakan bantuan perangkat lunak Statistical for Social Science versi 21.0 for windows. Pendekatan reliabilitas yang digunakan dalam penelitian ini adalah pendekatan konsistensi internal (internal consistency) dengan metode penyajian tunggal atau single-trial administration. Hasilnya yang didapatkan kemudian dianalisis dengan menggunakan Alpha Cronbach dengan bantuan program komputer Statistical for Social Science versi 21.0 for windows.

\section{Prosedur Pengambilan Data}

Pengambilan data diawali dengan mempersiapkan surat ijin penelitian dari Program Studi Psikologi Fakultas Kedoteran Universitas Udayana dengan nomor 094 /UN14.2.2.IV.4/2018 pada tanggal 28 Februari 2018. Selanjutnya peneliti menyebarkan surat ijin ke panti asuhan yang terpilih dari proses random dan memberikan izin, yaitu Panti Asuhan Darma Jati II, Panti Asuhan Tat Twam Asi, Panti Asuhan Sunya Giri, Panti
Asuhan Elisama, Panti Asuhan Anugerah, Panti Asuhan Tunas Bangsa, Panti Asuhan Jodie O'Shea House, Panti Asuhan Eben Haizer, Panti Asuhan Bala Keselamatan, Panti Asuhan Putra William Booth, Panti Asuhan Muhammadiyah, Panti Asuhan KH Mansyur Putri, Panti Asuhan KH Mansyur Putra, Panti Asuhan Sakinah, dan Panti Asuhan Hidayatuloh. Penyebaran surat ijin penelitian dilakukan pada tanggal 25 Januari 2018.

Proses pengambilan data dilakukan secara langsung kepada remaja yang tinggal di panti asuhan. Peneliti menjelaskan secara singkat mengenai penelitian yang dilakukan. Peneliti juga memberikan penjelasan terkait tata cara pengisian identitas diri dan pengisian kuesioner untuk nantinya dapat disampaikan kepada pihak yang mengisi kuesioner. Kuesioner yang disebarkan terdiri dari pengantar, identitas diri, petunjuk pengisian, skala motivasi berprestasi, dukungan sosial, dan efikasi diri. Total jumlah aitem yang terdapat dalam satu eksemplar kuesioner adalah 78 aitem yaitu 20 aitem motivasi berprestasi, 38 aitem dukungan sosial, dan 20 aitem efikasi diri. Pengambilan data mulai dilakukan pada tanggal 03 Maret 2018 sampai 11 Maret 2018.

Kuesioner diberikan kepada remaja awal dan tengah pada panti asuhan yang terpilih sesuai dengan kriteria responden pada penelitian. Ketika pengambilan kuesioner, peneliti memeriksa kembali kuesioner yang telah kembali untuk memastikan identitas diri dan semua pernyataan telah diisi oleh responden dengan lengkap, baik dan benar. Total jumlah kuesioner yang tersebar sebanyak 95 kuesioner. Total kuesioner terkumpul yang telah diisi dengan lengkap dan dapat dianalisis adalah 95 kuesioner.

\section{Teknik Analisis Data}

Analisis data pada penelitian ini menggunakan Uji Regresi Berganda untuk mengetahui apakah terdapat hubungan dukungan sosial dan efikasi diri dengan motivasi berprestasi pada remaja awal dan tengah yang tinggal di panti asuhan di Bali. Sebelum melakukan uji hipotesis, dilakukan uji asumsi penelitian yaitu uji normalitas dan uji linieritas. Pada penelitian ini uji normalitas menggunakan metode Kolmogorov-Smirnov (K-S) dengan taraf signifikansi nilai lebih dari 0,05 $(\mathrm{P}>0,05)$, sedangkan uji linieritas menggunakan uji Test for Linearity Compare Means dengan taraf signifikansi 0,05. Analisis data dilakukan dengan menggunakan bantuan perangkat lunak Statistical for Social Science versi 21.0 for windows.

\section{HASIL PENELITIAN}

\section{Karakteristik Subjek}

Responden dalam penelitian ini adalah remaja awal dan tengah berusia 12-17 tahun yang tinggal di panti asuhan berjumlah 95 orang. Mayoritas responden dalam penelitian ini adalah berjenis kelamin perempuan dengan persentase 58,9\%. Mayoritas penelitian berusia 17 tahun dengan persentase sebesar 23,2\%. Berdasarkan asal sekolah menunjukkan bahwa mayoritas asal sekolah responden penelitian berasal dari sekolah SMP Muhammadiyah 1 dengan persentase sebesar 24,2\%. Berdasarkan asal daerah menunjukkan bahwa mayoritas responden berasal dari Karangasem dengan persentase sebesar 
18,9\%. Berdasarkan lama tinggal di panti asuhan menunjukkan bahwa mayoritas responden telah lama tinggal di panti asuhan adalah 2 tahun dengan persentase sebesar 17,9\%.

\section{Deskripsi Data Penelitian}

Hasil deskripsi statistik data penelitian yaitu motivasi berprestasi, dukungan sosial dan efikasi diri dirangkum dalam tabel 1 (terlampir).

Hasil deskripsi statistik data penelitian pada Tabel 1 menunjukkan variabel motivasi berprestasi memiliki mean teoretis sebesar 50 dan mean empiris sebesar 60,52 dengan perbedaan sebesar 10,52. Hal ini menunjukkan bahwa responden penelitian memiliki taraf motivasi berprestasi yang tinggi karena nilai mean empiris lebih besar dibandingkan dengan mean teoretis $(60,52>50)$. Berdasarkan penyebaran frekuensi, responden dalam penelitian ini menghasilkan rentang skor antara 48 sampai dengan 76 .

Hasil deskripsi statistik data penelitian pada Tabel 1 menunjukkan variabel dukungan sosial memiliki mean teoretis sebesar 95 dan mean empiris sebesar 117,89 dengan perbedaan sebesar 22,89. Hal ini menunjukkan bahwa responden penelitian memiliki taraf dukungan sosial yang tinggi karena nilai mean empiris lebih besar dibandingkan dengan mean teoretis $(117,89>95)$. Berdasarkan penyebaran frekuensi, responden dalam penelitian ini meghasilkan rentang skor antara 93 sampai dengan 142.

Hasil deskripsi statistik data penelitian pada Tabel 1 menunjukkan variabel efikasi diri memiliki mean teoretis sebesar 50 dan mean empiris sebesar 58,11 dengan perbedaan sebesar 8,11. Hal ini menunjukkan bahwa responden penelitian memiliki taraf efikasi diri yang tinggi karena nilai mean empiris lebih besar dibandingkan dengan mean teoretis $(58,11>50)$. Berdasarkan penyebaran frekuensi, responden dalam penelitian ini meghasilkan rentang skor antara 41 sampai dengan 77 .

\section{Kategorisasi Data Penelitian}

Hasil pengkategorian skor motivasi berprestasi, dukungan sosial dan efikasi diri dapat dilihat pada Tabel 2,Tabel 3, dan Tabel 4 (terlampir).

Berdasarkan kategorisasi skor motivasi berprestasi di atas, dapat dilihat bahwa subjek yang memiliki taraf motivasi berprestasi yang tinggi sebanyak 65 orang atau persentase sebesar $68,4 \%$. Hal ini menunjukkan bahwa mayoritas subjek memiliki taraf motivasi berprestasi yang tinggi.

Berdasarkan kategorisasi skor dukungan sosial di atas, dapat dilihat bahwa subjek yang memiliki taraf dukungan sosial yang tinggi sebanyak 66 orang atau persentase sebesar 69,4\%. Hal ini menunjukkan bahwa mayoritas subjek memiliki taraf dukungan sosial yang tinggi.

Berdasarkan kategorisasi skor efikasi diri di atas, dapat dilihat bahwa subjek yang memiliki taraf efikasi diri yang tinggi sebanyak 61 orang atau persentase $64,2 \%$. Hal ini menunjukkan bahwa mayoritas subjek memiliki taraf efikasi diri yang tinggi. Uji Asumsi
Pada penelitian ini menggunakan tiga uji asumsi yang meliputi uji normalitas, uji linieritas dan uji multikolonieritas. Hasil uji normalitas dapat dilihat pada Tabel 5 (terlampir), hasil uji linieritas dapat dilihat pada Tabel 6 (terlampir), dan hasil uji multikolonieritas dapat dilihat pada Tabel 7 (terlampir).

\section{Sebaran data variabel motivasi berprestasi}

Berdasarkan hasil uji normalitas data penelitian pada Tabel 5, variabel motivasi berprestasi menunjukkan nilai KolmogorovSmirnov sebesar 1,015 dengan signifikansi sebesar 0,254 (p > $0,05)$. Hal ini menunjukkan bahwa data variabel motivasi berprestasi berdistribusi normal.

Sebaran data variabel dukungan sosial

Berdasarkan hasil uji normalitas data penelitian pada Tabel 5, variabel dukungan sosial menunjukkan nilai KolmogorovSmirnov sebesar 0,735 dengan signifikansi sebesar 0,652 ( $\mathrm{p}>$ $0,05)$. Hal ini menunjukkan bahwa data variabel dukungan sosial berdistribusi normal.

Sebaran data variabel efikasi diri

Berdasarkan hasil uji normalitas data penelitian pada Tabel 5, variabel efikasi diri menunjukkan nilai Kolmogorov-Smirnov sebesar 1.108 dengan signifikansi sebesar 0,171 ( $\mathrm{p}>0,05)$. Hal ini menunjukkan bahwa data variabel efikasi diri berdistribusi normal.

Hasil uji linieritas antara variabel motivasi berprestasi dan dukungan sosial

Berdasarkan hasil uji lineritas data pada Tabel 6, variabel motivasi berprestasi dan dukungan sosial memiliki hubungan yang linier karena nilai signifikansi pada kolom linearity menunjukkan angka $0,000(\mathrm{p}<0,05)$, dan nilai signifikansi pada kolom deviation from linearity menunjukkan angka 0,804 $(>0,05)$.

Hasil uji linieritas antara variabel motivasi berprestasi dan efikasi diri

Berdasarkan hasil uji lineritas data pada Tabel 6, variabel motivasi berprestasi dan efikasi diri memiliki hubungan yang linier karena nilai signifikansi pada kolom linearity menunjukkan angka $0,000(\mathrm{p}<0,05)$, dan nilai signifikansi pada kolom deviation from linearity menunjukkan angka 0,642 $(>0,05)$.

Berdasarkan hasil uji multikolonieritas data penelitian pada Tabel 7, dapat dinyatakan bahwa tidak terjadi multikolonieritas diantara kedua variabel bebas penelitian yaitu dukungan sosial dan efikasi diri. Hal ini ditunjukkan dengan nilai VIF sebesar 1,260 (dibawah 10) dan nilai tolerance sebesar 0,794 (di atas $0,1)$.

Uji hipotesis dalam penelitian ini dilakukan dengan menggunakan analisis regresi berganda.

Berdasarkan Tabel 8 (terlampir), dapat dilihat bahwa terdapat nilai $\mathrm{R}$ yang merupakan koefisien regresi sebesar 0,574 dan nilai adjusted $\mathrm{R}$ square (R2) yang merupakan nilai koefisien determinasi sebesar 0,329. Nilai adjusted R2 menunjukkan besarnya peran atau sumbangan dari kedua variabel bebas terhadap variabel tergantung dalam uji regresi berganda yang melibatkan lebih dari dua variabel. Hasil uji regresi berganda antara variabel bebas dan variabel tergantung yang ditunjukkan pada Tabel 8 memiliki arti yaitu dukungan sosial dan efikasi 
diri secara bersama-sama memberikan sumbangan dan menentukan taraf motivasi berprestasi sebesar 31,5\%, sedangkan $68,5 \%$ ditentukan oleh faktor-faktor lain diluar penelitian ini.

Nilai signifikansi $\mathrm{F}$ yang dihasilkan dari uji regresi pada Tabel 9 (terlampir) adalah sebesar $0,000(\mathrm{p}<0,05)$. Hasil ini menunjukkan bahwa model regresi dalam penelitian ini dapat digunakan untuk memprediksi variabel tergantung yaitu motivasi berprestasi. Berdasarkan hasil yang didapatkan, maka dapat disimpulkan bahwa dukungan sosial dan efikasi diri secara bersama-sama berhubungan terhadap motivasi berprestasi.

Berdasarkan Tabel 10, didapatkan beberapa hasil yaitu sebagai berikut: (a) Nilai koefisien beta terstandarisasi (standardized coefficients beta) pada variabel dukungan sosial lebih besar dari nilai koefisien beta terstandarisasi pada variabel efikasi diri $(0,368>0,303)$. Artinya, dukungan sosial memiliki hubungan yang lebih besar terhadap kemampuan motivasi berprestasi subjek dibandingkan dengan efikasi diri. (b) Nilai t sebesar 3,844 dan nilai signifikansi sebesar 0,000 ( $\mathrm{p}<0,05)$ pada variabel dukungan sosial menunjukkan bahwa dukungan sosial memiliki hubungan yang signifikan terhadap motivasi berprestasi. (c) Nilai t sebesar 3,164 dan nilai signifikansi sebesar 0,002 $(\mathrm{p}<0,05)$ pada variabel efikasi diri menunjukkan bahwa efikasi diri memiliki hubungan yang signifikan terhadap motivasi berprestasi.

Berdasarkan hal tersebut, maka dapat disimpulkan Ha di terima yang berarti terdapat hubungan dukungan sosial dan efikasi diri dengan motivasi berprestasi pada remaja yang tinggal di panti asuhan di Bali.

\section{PEMBAHASAN DAN KESIMPULAN}

Berdasarkan hasil penelitian yang telah didapatkan dan dianalisis dengan menggunakan teknik regresi berganda, dapat diketahui bahwa hipotesis mayor penelitian yaitu dukungan sosial dan efikasi diri memiliki hubungan dengan motivasi berprestasi pada remaja yang tinggal di panti asuhan di Bali dapat diterima. Hal ini dapat dilihat dari koefisien $\mathrm{R}$ pada hasil uji regresi adalah sebesar 0,574 , dan nilai $F$ sebesar 22,577 dengan signifikansi sebesar 0,000 yang menunjukkan bahwa dukungan sosial dan efikasi diri secara bersama-sama berhubungan dengan motivasi berprestasi. Koefisien determinasi sebesar 0,315 menunjukkan bahwa kedua variabel bebas yaitu dukungan sosial dan efikasi diri memiliki sumbangan efektif sebesar 31,5\% terhadap variabel tergantung yaitu motivasi berprestasi. Berdasarkan hasil yang didapatkan, dapat ditarik kesimpulan bahwa dukungan sosial dan efikasi diri menentukan 31,5\% taraf motivasi berprestasi yang dimiliki remaja awal dan tengah yang tinggal di panti asuhan di Bali. Sebesar 68,5\% lainnya dipengaruhi oleh variabel lain yang tidak dimasukan dalam penelitian ini.

Hasil analisis koefisien beta terstandarisasi dari dukungan sosial menunjukkan nilai sebesar 0,368 , nilai t sebesar 3,844 , dan signifikansi $0,000(\mathrm{p}<0,005)$, sehingga dukungan sosial berhubungan secara signifikan dengan motivasi berprestasi pada remaja awal dan tengah yang tinggal di panti asuhan di Bali. Neseth, Savage, Navarrano (2009) mengatakan bahwa terdapat hubungan dukungan sosial dengan motivasi berprestasi. Hasil penelitiannya juga menyimpulkan bahwa remaja mendapat dukungan sosial bukan hanya dari orangtua tetapi juga orang-orang lainnya yang berada disekitarnya, seperti teman dan guru di sekolah yang dapat menunjang pencapaian motivasi berprestasi remaja.

Pada deskripsi statistik data penelitian menunjukkan subyek dengan taraf dukungan sosial tinggi sebesar 69,4\%. Tingginya taraf dukungan sosial pada remaja awal dan tengah yang tinggal di panti asuhan di Bali didasari oleh pengaruh dari lingkungan (Lopez, 1997). Hasil ini sejalan dengan penelitian yang dilakukan oleh SilviaQutrinida (2016) menunjukkan bahwa terdapat hubungan yang positif antara dukungan sosial dengan motivasi berprestasi pada siswa kelas VII regular SMP Plus Yayasan Pondok Pesantren, hal ini dapat disimpulkan bahwa dukungan sosial yang datang tidak harus dari keluarga. Remaja lebih banyak menghabiskan waktu bersama teman-teman, mengenal lingkungan yang baru, guru baru, dan sebagainya. Kebanyakan dari remaja setiap harinya tidak lepas dari komunikasi dengan orangtua, dan tidak pergi ke pondok pesantren secara paksaan, sehingga remaja yang tinggal di pondok tersebut tidak mengalami beban dan hampir tidak memiliki masalah yang membuat motivasi berprestasinya menurun semakin banyak dukungan sosial yang mereka dapatkan maka semakin tinggi pula motivasi berprestasinya.

Hasil analisis koefisien beta terstandarisasi dari efikasi diri menunjukkan nilai sebesar 0,303 , nilai t sebesar 3,164, dan signifikansi 0,002 $(p<0,05)$, sehingga efikasi diri berhubungan secara signifikan dengan motivasi berprestasi pada remaja awal dan tengah yang tinggal di panti asuhan di Bali. Hasil penelitian ini sejalan dengan penelitian oleh Bandura (1997) menunjukkan bahwa efikasi diri dan motivasi berpestasi merupakan faktor yang paling berpengaruh terhadap kinerja akademik siswa.

Pada deskripsi statistik data penelitian menunjukkan subyek dengan taraf efikasi diri tinggi sebesar 64,2\%. Menurut Pervin dan John (dalam Bandura, 1997) menyatakan bahwa individu yang mempunyai efikasi diri yang tinggi akan lebih memiliki motivasi belajar untuk dapat berprestasi yang tinggi pula. Hal ini dicerminkan dengan besarnya usaha yang dilakukan serta ketekunannya dalam mengatasi rintangan-rintangan yang ada.

Efikasi diri yang tinggi dapat membuat remaja terus mengerjakan tugas-tugasnya dan tidak mudah menyerah dan bertahan apabila menemui kesulitan-kesulitan, serta akan berusaha lebih keras didalam mengatasi rintangan-rintangan yang ada. Feist dan Feist (2013) menyatakan bahwa efikasi diri merujuk pada keyakinan diri individu atas kemampuan dalam melakukan sesuatu tindakan. Individu akan lebih mungkin untuk bertindak dan lebih mungkin untuk menjadi sukses apabila memiliki keyakinan untuk dapat melakukan sesuatu yang mempunyai potensi untuk dapat mengubah kejadian di lingkungannya.

Nilai koefisien beta terstandarisasi dukungan sosial lebih besar daripada nilai koefisien beta terstandarisasi efikasi diri. Hal 
tersebut menunjukkan bahwa dukungan sosial memiliki hubungan lebih besar dengan motivasi berprestasi dibandingkan hubungan efikasi diri dengan motivasi berprestasi. Individu yang mendapatkan dukungan sosial cenderung akan percaya bahwa dirinya dihargai, dicintai, diperhatikan serta merupakan bagian dari kelompok sosial yaitu keluarga, rekan kerja dan teman dekat. Hal ini sejalan dengan penelitian Hayes (2012) mengungkapkan terdapat hubungan antara keterlibatan dari orangtua dengan motivasi berprestasi anak, dengan kata lain memberikan pengasuhan dengan segala kasih sayang dan dukungan yang baik merupakan salah satu faktor penting untuk menunjang motivasi berprestasi anak.

Pada deskripsi statistik data penelitian menunjukkan subyek dengan taraf motivasi berprestasi tinggi sebesar 68,4\%. Tingginya taraf motivasi berprestasi pada remaja awal dan tengah yang tinggal di panti asuhan di Bali disebabkan oleh tingginya taraf dukungan sosial dan efikasi diri pada penelitian ini. Hasil analisis data dengan teknik regresi berganda menunjukkan kedua variabel bebas tinggi, maka dengan sendirinya taraf variabel tergantung akan tinggi. Ketika seseorang remaja memiliki motivasi berprestasi yang tinggi, ia akan cenderung bertanggung jawab atas tugas yang dikerjakannya dan tidak akan meninggalkan tugas tersebut sebelum berhasil menyelesaikannya, ia juga akan memilih tugas dengan taraf kesulitan tinggi, walaupun tugas itu sulit baginya tetapi individu tersebut tetap akan berusaha menyelesaikan tugas itu dan berani menanggung resiko bila mengalami kegagalan, remaja yang memiliki motivasi berprestasi cenderung kreatif dan tidak menyukai pekerjaan rutin, remaja juga menyukai umpan balik, karena akan memperhatikan kesalahan-kesalahan yang dilakukannya, serta remaja akan berusaha menyelesaikan setiap tugas dalam waktu secepat mungkin dan sefisien mungkin (McClleland, 1987).

\section{DAFTAR PUSTAKA}

Amalia, Lely dan Indera Ratna Irawati Pattinasarany.2014. Hubungan Antara Motivasi Berprestasi dan Dukungan Sosial Dengan Prestasi Akademik Pada Anak Kelas VIII dan IX SMP di Panti Asuhan.Fisip UI.

Bandura, A. 1997. Self-efficacy: Toward a Unifying of Behavioral Change. Psychological Review. 84 (2): 191-215.

Damyati \& Mudjiono. 2006. Belajar dan Pembelajaran. Jakarta: PT. Rineka Cipta.

Dimatteo, M.R. 2004. Social support and patient adherence to medical treatment: a meta analysis. Health Psychology Journal, 23, $2,207-218$

Feist, Jess, Gregory JF. 2013. Theories of Personality. Ed. 8.Singapore : McGraw-Hill

Gunarsa, Singgih D. 2008. Psikologi Anak: Psikologi Perkembangan Anak dan Remaja. Jakarta : PT BPK Gunung Mulia.

Hayes, D.CMarquis. 2012. Parental Involvement and Achievement outcomes in African American Adolscene. Proquest Journal of Comporative Family Studies 43.4. P. 567 XL

Lopez,Eric Joseph. 1997. TheAcculturation,SocialSupport and Motivation Achievment of Ninth Grade Mexican High School Student. ProQuest, UMI, Dissertation and These.(http://search.proquest.com/docview/304343153/fullt extPDF/DE0CD787DD34879PQ/4?accountid=17242)

McClelland, D.C. 1987. Human Motivation. New York: The Press Syndicate of The University of Chambridge.
Nelson, Behrman, Robert M, Kliegman, (1996), Ilmu Kesehatan Anak Nelson Volume 3 Edisi 15. Jakarta: EGC.

Neseth, Hans, Savage, Todd A. Navarro, R 2009. Examining the Impact Acculturation and Perceived Social Support on Mathematics Achievment Among latino/a High School Student The California School Psychologist 14. (http://searchproquest.com/docview/200779137/fulltextPD F/14150AF3478BD2FCB/1? accountid=17242).

Oren, Nihal. 2012. Hopelessness Level of Children Living with Their Parent or in an Orphanage. Journal of Social Behavior and Personality, 40,3,501. Proquest. (http://search.proquest.com/docview/1008565989/94892A DI70F647F6PQ/1? accountid=17242).

Qotrunnada, Silvia. 2016. Hubungan Dukungan Sosial dengan Motivasi Berprestasi pada siswa kelas VII SMP Plus Yayasan Pondok Pesantren Darrussalam Banyuwangi. (Skripsi) Fakultas Psikologi Universitas Islam Negeri Maulana Malik Ibrahim. Malang

Santrock J.W.2003, Adolscence (Perkembangan Remaja) (6th ed). University of Texas at Dallas. Jakarta: Gelora Aksara Persada Erlangga.

Santrock, J.W. 2007.Perkembangan Anak. Jilid 1 Edisi Kesebelas.Jakarta : PT. Erlangga

Sarafino, E.P. \& Smith, T.W. 2011.Health Psychology: Biopsychosocial Interactions (7thed.). New York: Wiley.

Sarafino. 1994. Health Psychology Biopsychosocial Interaction. USA: John Wiley \& Sons.

Stevenson, M. 1952. Some Emotional Problem of Orphanage Children. Carnadian Journal of Psychology/ Revue Canadienne de psychology, 6,4,. 178-182. (search. Proquest.com/ docview/614267209/fulltextPDF/D192441B365B4D9CPQ/ 2? acco untid $=17242$ ).

Sugiyono. 2014. Metode Penelitian Kuantitatif, Kualitatif, dan Kombinasi (Mixed Methods). Bandung: Alfabeta

Teja, M. 2014. Perlindungan terhadap Anak Terlantar di Panti Asuhan.Artikel Kesejahteraan Sosial, VI (5).

Winkel, W.S. 1996. Psikologi Pengajaran.cet. Ke-3. Jakarta:Grasindo 


\section{LAMPIRAN}

Tabel 1

Deskripsi statistik data penelitian

\begin{tabular}{ccccccccc}
\hline Variabel & $\mathbf{N}$ & $\begin{array}{c}\text { Mean } \\
\text { Teoretis }\end{array}$ & $\begin{array}{c}\text { Mean } \\
\text { Empiris }\end{array}$ & $\begin{array}{c}\text { Std. } \\
\text { Deviasi } \\
\text { Teoretis }\end{array}$ & $\begin{array}{c}\text { Std. } \\
\text { Deviasi } \\
\text { Empiris }\end{array}$ & $\begin{array}{c}\text { Sebaran } \\
\text { Teoretis }\end{array}$ & $\begin{array}{c}\text { Sebaran } \\
\text { Empiris }\end{array}$ & Nilai t \\
\hline MB & 95 & 50 & 60,52 & 10 & 5,399 & $20-80$ & $48-76$ & $\begin{array}{c}18,985 \\
(\mathrm{p}=0,000)\end{array}$ \\
DS & 95 & 95 & 117,89 & 19 & 9,706 & $38-152$ & $93-142$ & $\begin{array}{c}22,992 \\
(\mathrm{p}=0,000) \\
14,754 \\
(\mathrm{p}=0,000)\end{array}$ \\
\hline
\end{tabular}

Tabel 2

Kategorisasi skor motivasi berprestasi

\begin{tabular}{cccc}
\hline Rentang Nilai & Kategori & Jumlah & Persentase \\
\hline $\mathrm{X} \leq 35$ & Sangat Rendah & 0 & $0 \%$ \\
$35<\mathrm{X} \leq 45$ & Rendah & 0 & $0 \%$ \\
$45<\mathrm{X} \leq 55$ & Sedang & 15 & $15,8 \%$ \\
$55<\mathrm{X} \leq 65$ & Tinggi & 65 & $68,4 \%$ \\
$65<\mathrm{X}$ & Sangat Tinggi & 15 & $15,8 \%$ \\
\hline
\end{tabular}

Tabel 3

Kategorisasi skor dukungan sosial

\begin{tabular}{cccc}
\hline Rentang Nilai & Kategori & Jumlah & Persentase \\
\hline $\mathrm{X} \leq 66,5$ & Sangat Rendah & 0 & $0 \%$ \\
$66,5<\mathrm{X} \leq 85,5$ & Rendah & 0 & $0 \%$ \\
$85,5<\mathrm{X} \leq 104,5$ & Sedang & 7 & $7,4 \%$ \\
$104,5<\mathrm{X} \leq 123,5$ & Tinggi & 66 & $69,4 \%$ \\
$123,5<\mathrm{X}$ & Sangat Tinggi & 22 & $23,2 \%$ \\
\hline
\end{tabular}

Tabel 4

Kategorisasi skor efikasi diri

\begin{tabular}{cccc}
\hline Rentang Nilai & Kategori & Jumlah & Persentase \\
\hline $\mathrm{X} \leq 35$ & Sangat Rendah & 0 & $0 \%$ \\
$35<\mathrm{X} \leq 45$ & Rendah & 1 & $1,0 \%$ \\
$45<\mathrm{X} \leq 55$ & Sedang & 33 & $34,7 \%$ \\
$55<\mathrm{X} \leq 65$ & Tinggi & 61 & $64,2 \%$ \\
$65<\mathrm{X}$ & Sangat Tinggi & 5 & $5,2 \%$ \\
\hline
\end{tabular}


Tabel 5

Hasil uji normalitas variable penelitian

\begin{tabular}{lcc}
\hline \multicolumn{1}{c}{ Variabel } & Kolmogorov-Smirnov & Asymp. Sig (2-tailed) \\
\hline Motivasi Berprestasi & 1,015 & 0,254 \\
Dukungan Sosial & 0,735 & 0,652 \\
Efikasi Diri & 1.108 & 0,171 \\
\hline
\end{tabular}

Tabel 6

Hasil uji linieritas variabel penelitian

\begin{tabular}{|c|c|c|c|c|}
\hline & & & $\mathbf{F}$ & Sig. \\
\hline Motivasi & Between & Linearity & 29,286 & 0,000 \\
\hline Berprestasi*Dukungan & Group & Deviation from & 0,758 & 0,804 \\
\hline Sosial & & Linearity & & \\
\hline Motivasi Berprestasi* & Between & Linearity & 25,634 & 0,000 \\
\hline Efikasi Diri & Group & $\begin{array}{l}\text { Deviation from } \\
\text { Linearity }\end{array}$ & 0,855 & 0,642 \\
\hline
\end{tabular}

Tabel 7

Hasil uji multikolinier antar variabel bebas

\begin{tabular}{cccl}
\hline Variabel & Tolerance & $\begin{array}{c}\text { Variance } \\
\text { Inflation Factor } \\
\text { (VIF) }\end{array}$ & Keterangan \\
\hline Dukungan Sosial & 0,794 & 1,260 & $\begin{array}{l}\text { Tidak terjadi } \\
\text { multikolonieritas }\end{array}$ \\
Efikasi Diri & 0,794 & 1,260 & $\begin{array}{l}\text { Tidak terjadi } \\
\text { multikolonieritas }\end{array}$ \\
\hline
\end{tabular}

Tabel 8

Uji hasil regresi berganda nilai $\mathrm{R}^{2}$

\begin{tabular}{cccc}
\hline $\mathbf{R}$ & $\mathbf{R}$ Square & Adjusted $\mathbf{R}$ Square & Std. Error of the Estimate \\
\hline 0,574 & 0,329 & 0,315 & 4,469 \\
\hline
\end{tabular}


Tabel 9

Hasil uji regresi berganda signifikansi nilai $\mathrm{F}$

\begin{tabular}{lccccc}
\hline & Sum of Squares & Df & Mean Square & F & Sig. \\
\hline Regression & 901,971 & 2 & 450,985 & 22,577 & $.000^{6}$ \\
\hline Residual & 1837,756 & 92 & 19,976 & & \\
\hline Total & 2739,726 & 99 & & & \\
\hline
\end{tabular}

Tabel 10

Hasil uji regresi berganda nilai koefisien beta dan nilai $\mathrm{T}$

\begin{tabular}{cccccc}
\hline Model & \multicolumn{2}{c}{$\begin{array}{c}\text { Unstandardized } \\
\text { Coefficients }\end{array}$} & $\begin{array}{c}\text { Standardized } \\
\text { Coefficients }\end{array}$ & T & Sig. \\
\cline { 2 - 4 } & $\mathbf{B}$ & Std. Error & Beta & & \\
\hline (Constant) & 18,588 & 6,260 & & 2,970 & 0,004 \\
Dukungan Sosial & 0,205 & 0,053 & 0,368 & 3,844 & 0,000 \\
Efikasi Diri & 0,306 & 0,097 & 0,303 & 3,164 & 0,002 \\
\hline
\end{tabular}

